\title{
EVALUATION OF VARIETAL, INFOCHEMICALS AND BIO-PESTICIDAL EFFECTS IN THE MANAGEMENT OF CUCUMBER BEETLES IN CUCUMBER (CUCUMIS SATIVUS LINN.) IN THE SOUTHERN GUINEA SAVANNA
}

\author{
Kabeh J.D.*, Eke H.O. and Balogun K.
}

Crop Production and Protection Department, Faculty of Agriculture and Life Sciences. Federal University Wukari, P.M.B. 1020. Wukari, Taraba State, Nigeria

Email: drkabeh4u@gmail.com; hillaryeke6@gmail.com; kerimubalogun@gmail.com

$$
\text { Mobile: +234 8032511906, +2347037582017, +2347061931598. }
$$

Cite this article:

Kabeh J.D., Eke H.O.,

Balogun K. (2021), Evaluation of Varietal, Infochemicals and Bio-pesticidal Effects in the Management of Cucumber Beetles in Cucumber (Cucumis Sativus Linn.) in the Southern Guinea Savanna. African Journal of Agriculture and Food Science 4(3), 1-13. DOI: $10.52589 / A J A F S-$ YMSKZWF8.

\section{Manuscript History}

Received: 4 June 2021

Accepted: 30 June 2021

Published: 20 July 2021

Copyright $\odot 2020$ The Author(s). This is an Open Access article distributed under the terms of Creative Commons AttributionNonCommercial-NoDerivatives 4.0 International (CC BY-NC-ND 4.0 ), which permits anyone to share, use, reproduce and redistribute in any medium, provided the original author and source are credited.
ABSTRACT: The experiments were laid out in the Teaching and Research farms of Federal University Wukari, Nigeria. Six cucumber cultivars were treated on varietal effects; five infochemicals and a control for second experiment, while four bio-pesticides materials, Cypermethrin and untreated control were also studied. Each treatment was laid out in RCBD and replicated three times. The vine length was higher in cultivars Penino and Seminis, $50.87 \mathrm{~cm}$ and $50.70 \mathrm{~cm}$ respectively, number of branches were uniform, but Poinsett had larger leaves area $141.33 \mathrm{~cm}^{2}$, hence higher yield (141.67) and much heavier fruits $31.30 \mathrm{~g}$, both were not significantly different $(P>0.05)$. Mean fruit damage was highest in Griffaton (4.55), Seminis gave longer and larger fruit sizes. Marketer had high pests' invasion (200.33). Naphthalene treated plants gave better growth, and yields, 164.67, weighing 38.07g. Other infochemicals performed below the untreated control. Average fruit damage was least in cinnamon oil treated plots, but fruits length and diameter were uniform across the treatments. The untreated control had higher pest beetle population effects. Better yields were recorded in ANSE treated cucumber plants (186.00), heavier fruits and less fruit damage recorded in the Cypermethrin treated crops, but a higher beetle population was in control. The bio-pesticides gave varied levels of protection. Combining varietal, info chemicals and bio-pesticides impacts secures marketable fruits. This study lacks explanations on differences in relative beetle population, fruit yield inconsistencies, weight and variability recorded across the experiments. However, further studies will improve the results of these studies. Also, statistically significant impacts were difficult to prove, probably due to the low number of plots that reduced the power of our data, leading to type 2 error masking important differences.

KEYWORDS: Cucumber Cultivars, Beetles, Yield Components, Info-Chemicals, Bio-Pesticides. 


\section{INTRODUCTION}

Cucumber (Cucumis sativus, Linn.) is one of the most important exotic vegetables cultivated in Nigeria and one of the best foods for the body's overall health (Natural News, 2014; Umeh and Ujiako, 2018). Enhanced productivity depends on farm resources' efficient use (Adeyemo and Kuhlmann, 2009). The crop is a valuable source of conventional anti-oxidant, rich in vitamins, B6, C, and K, beta-carotene, Flavonoids, Manganese and Silicon (Natural News, 2014).

Bulk production from Jos, Plateau State sustains demand from southern Nigeria, where these salad vegetables augment high intake of carbohydrate, hence high prices (Ayoola and Adeniran, 2006). In Nigeria, cucumber production and market rates had not been well determined.

Significant yield may be quantified by factors such as fruit quality, size, or prices at the market and export gates, determined by season (Okonmah, 2011). Furthermore, market standards may be less rigid but malformed fruits or those with pest damage symptoms are not marketable.

Quesada et al.(1995) reported that cucurbitacin and other phytochemicals induction can have high impacts, especially those associated with pests, which possess high energy costs particularly in agricultural crops. The blend of positive and negative feedback associated with these cultivar differences may account for the difficulty in giving significant results on dynamics of insect-plant relationship.

The striped and spotted cucumber beetles Acalymna vittatum F., and Diabrotica undecimpuntata howardi Bardes, share status as Economic pests of Cucumber production and notorious challenges of control. These pests primarily account for up to 10 annual synthetic pesticide application on conventional farms, contributing to over 35 confirmed pesticide residues on cucumbers (Punzi et al., 2005). Organic farming, polycultures, bio-pesticides, trap croppings and bio-rational efforts are prime to subvert synthetic poisonings and environmental contamination (Harsimram et al., 2017).

Greatest yield losses occur when host crops are small with only cotyledon leaves or few true leaves, while herbivory on older plant and reproductive structures and fruits may impact heavily on yield through vectoring bacterial wilt (Erwinia tracheiphila) disease (Hoffmann et al.,2000; Diver and Hinmann, 2000; Bessin, 2010; Webb, 2010). These pests cause yield losses between 5 to $30 \%$ (Onovo, 1992) while severity of the disease effect may lead to zero yield (Jeffrey, 2001; Synder, 2012; Erika et al., 2015; Umeh and Ojiako, 2018). Hoards of cucumber beetles recorded in most studies exceed the one beetle per plant economic thresholds in most cultivars in most experimental fields (Diver and Hinmann, 2008).

Info-chemicals induce behavioural and physiological responses in individuals and groups with reduced environmental impacts and non-target effects. Heusken, et al. (2011) reported pest population tracking, dispersals, detection and monitoring economically important pests as attractants, synergist, mass trapping, mating disruptant and anti-aggregants benefits of infochemicals (Cook et al., 2007; Clarke and Strom, 2011). Cucurbits produce extremely bitter cucurbitacin compounds that enhance herbivory (Hoffmann et al., 2003; McGuire and Agrawal, 2005). 
Herbivory damage may induce other phytochemical reactions with mixed effects e.g floral terpenoids attract heavier beetles feeding and lower resistance to diseases (Moran, 2001). Furthermore, peroxidase can be used as bait on traps, Cinnamon and Clove oils and phenolics inhibit feeding in cucumber beetles (Metcalf et al., 1980; Theis et al., 2009).

Vander kraan and Ebbers (1990) found the impact of temperature over wind speed on the kinetics of release rates to be independent of the amount of active agent in the info-chemical in dispenser increasing exponentially with temperature. Other non-host volatiles like camphor, lemon, eucalyptus oils, methyl salicylate, $(Z)$ - jasmine, and other essential oils, mask or evoke non host avoidance and repellant behaviours like rejection, reduced colonization due to poor quality hosts, which impacts positively on herbivory (Riddick et al., 2010; Bruce et al., 2005a; Isman, 2006 and Pickett and Glin Wood, 2007).

Bio-pesticides management of these beetles is evidenced by less damage to the vegetative parts and yield output advantage (Abdul-kalam, et al., 2013; Ivase et al., 2017). Phytochemicals have been used for many years to control insect pest damage on agricultural crops. Plants produce a wide range of secondary metabolites, e.g. terpenoids, alkaloids and phenolics that often possess pesticidal properties acting as antifeedant, growth retardant and direct mortalities (Wheeler and Isman, 2001).

Cucumber cultivars show varied susceptibility to these beetles. Heavy seedling loss of cucumbers under certain conditions as high beetle pressure, excellent control is achievable by bio-pesticides. Emeasor and Nwaliri (2012) ranked the percentage damage caused by $L$. Orbornalis on eggplants protected with bio-pesticides that gave least damage thresholds. Hamman et al., (2012) also reported significant yield advantage of bio-pesticides treated cowpeas over the untreated (control) in relation to pest population, thus recommending these plant extracts potentials as substitutes to synthetics in crop production. Furthermore, yield of marketable fruits in treated plots were 3 times over the control plots, giving up to $70 \%$ yield advantage in foliar spray over untreated plots (Eifediyi and Remison,2010;Kumar and Singh,2015; Tijjani et al., 2016).

This study aimed to search for alternative management strategies against the cucumber beetle infestation, reduce risk of residue contamination of synthetics and economic losses of the smallholder cucumber production in the study area.

\section{METHODOLOGY}

The experiment was conducted in the Southern Guinea Savanna region, Wukari, Taraba State, Nigeria on Lat. $07^{0} 85^{\prime} \mathrm{N}$; Long. $09^{\circ} 68^{\prime}-89^{\prime} \mathrm{E}$, at an altitude $152 \mathrm{~m}$ above sea level with mean annual temperature and rainfall $24^{\circ}-33^{\circ} \mathrm{C}$ and $800-1450 \mathrm{~mm}$ respectively, and $78 \%$ relative humidity, rainfall pattern is modal from April - October and dry season November - March every year.

Soil analysis of the research farm gave textural class as sandy soil, with percentage organic matter content and total Nitrogen $=2.35$ and 0.98 , while available $\mathrm{P}\left(\mathrm{mgl}^{-1}\right)=0.52$. Exchangeable $\mathrm{K}, \mathrm{Na}, \mathrm{Ca}, \mathrm{Mg}$ and acidity $(\mathrm{Mol} / \mathrm{kg})=1.6 ; 2.1 ; 3.8 ; 1.8$ and 1.10 respectively. 


\section{Experimental Design}

Three experiments were laid out. Experiment one evaluates response of six cucumber cultivars on yields and cucumber beetles population density; experiment two evaluates effects of six info-chemicals on the most susceptible cultivar, while experiment three observes protectant effects of bio-pesticides against the cucumber beetles.

The experiments were laid out in RCBD, with three replications each, six cucumber cultivars were the treatments, (Premier, Griffaton; Seminis, Marketer, Poinsett and Pepino). The experimental fields were cleared of stumps ploughed and harrowed for fine tilt. A field size of 10 metres x 11 metres $\left(110 \mathrm{~m}^{2}\right)$ were marked out and demarcated into three blocks each containing six plots of $3 \mathrm{~m} \times 2 \mathrm{~m}\left(6 \mathrm{~m}^{2}\right)$ each, at $1 \mathrm{~m}$ interval within replications and $2 \mathrm{~m}$ intervals between replications.

Three cucumber seeds per cultivars were planted per hill at $2.5 \mathrm{~cm}$ depth and $20 \mathrm{~cm} \times 20 \mathrm{~cm}$ interval, a total of 1,080 treated seeds were sown giving 20 stands (hills) in each plot, using $\lambda$-cyhalothrin (knock off) insecticides and metalaxyl (Ridomil) fungicides treatment. At one week after germination stakes were provided for the trailis, other agronomic practices were strictly observed.

The experimental layout for evaluating the effectiveness of info-chemical in protecting cucumber has the same design as above except the most susceptible cultivar, Marketer, was used for the trial. While info-chemicals, cinnamon oil, naphthalene; methylated spirit, vitamin B-complex, methyl- salicylate and a control, form the treatments, and each treatment was replicated three times in a RCBD. Measured amounts of each info-chemical were placed in an improvised dispenser of perforated cellophane envelope enclosing cotton wools as absorbents and each were padded with a piece of hard cardboard paper cut-out and banded with masking tape along the edges. These improvised dispensers were hung on stakes $1 \mathrm{~m}$ above the ground according to the experimental treatment in the middle of individual plots. Using $2 \mathrm{mls}$ needle and syringe, the liquid chemicals were administered into the dispensers at $2 \mathrm{ml}$ quantity; this setup was repeated at weekly intervals, after each pest population counts.

Furthermore, the bio-pesticidal properties of six botanicals limiting activities of the cucumber beetles on smallholder cucumber production had similar design, the field trial was laid out in RCBD with six treatments having three replications each. Five aqueous botanical extracts of Azadirachta (neem) seeds, Delonix seeds, Parkia seeds, Vernonia leaves, a synthetic positive check Cypermethrin and an untreated control.

The bio-pesticides were obtained from plantations within the Wukari Local Government Area. These were cleaned and dried at room temperature for seven days before pulverizing. $100 \mathrm{~g}$ each were dissolved in one litre distilled water for 24 hours using a muslin cloth as filter. The aqueous filtrate was applied undiluted immediately. The application frequency was twice a week. Similarly, pest population count was recorded before every treatment, while damage severity was recorded and data on agronomic and yield components recorded throughout the experimental period after the methods of Abdul-kalam et al. (2013) and Harsimran et al. (2017). 


\section{Data Collection}

Four middle plant stands were tagged from each plot as subplot. Data was collected from the sub plots. Emergence count, days to $50 \%$ emergence, vine length, number of branches, number of leaves, leaf area, fruit length and diameter, number of fruits per plant, fresh fruit weight, number of damaged fruits per plots, total yield/plots and cucumber beetles census, were recorded twice a week.

The data of three replications were pooled together treatment wise and averaged before analysis using one way ANOVA ( $\mathrm{P} \geq 0.05)$ for $\mathrm{RCBD}$, while significant differences between treatment means identified and separated using Turkey HSD test at 5\% level of significance. The results are presented in tables $1-3$ and discussed accordingly.

\section{RESULTS}

Table 1.0,the vegetative components gave the following parameters; vine lengths $(\mathrm{cm})$ for the cultivar Penino $50.87 \mathrm{~cm}$, and Seminis $50.70 \mathrm{~cm}$ as highest, while Griffaton and Premier had $39.80 \mathrm{~cm}$ and $39.57 \mathrm{~cm}$ as the lowest vine length, however, vine lengths were not significantly different.

Furthermore, mean branchings were uniform throughout the cultivars having SEM, 0.33 and coefficient of variation $21.65 \%$. Leaf area was higher in Poinsett $141.33 \mathrm{~cm}$ as against $105.80 \mathrm{~cm}$ in Premier, this also translates into higher yield of 141.67, being significantly different $(\mathrm{P}<0.05)$ from yields of other varieties and also significantly better fruit weight (31.30) at 5\% level of significance according to Turkey HSD pairwise comparison test $(\mathrm{P}<$ $0.05)$.

The mean number of damaged fruits was uniform across the varieties being highest in Griffaton (4.55) and Seminis (4.00). Fruit lengths of $18.33 \mathrm{~cm}$ and $16.50 \mathrm{~cm}$ were recorded in Seminis and Poinsett cultivars respectively, while $18.93 \mathrm{~cm}$ and $17.67 \mathrm{~cm}$ diameters for Seminis and Premier. The mean pest beetle population was highest in marketer 200.33 and lowest in 151.00 for Griffaton cultivar respectively, which however were not statistically different $(\mathrm{P}>0.05)$ and coefficient of variation of $18.38 \%$.

Table 2 results gave mean effects of info-chemicals on the cucumber, marketer as the most susceptible cultivar infested by the cucumber beetles. Vine length was significantly different $(\mathrm{P}<0.05)$ across the treatments, being longer in naphthalene treated plants. Mean number of branches were uniform, $2.25-3.25$, and leaf area of $174.99 \mathrm{~cm}$ in naphthalene treated cucumber plots. This accounted for a high yield difference of 164.67 , weighing heavier $(38.07 \mathrm{~g})$ than fruits yield from other info-chemical treatments, while B-complex vitamin and methyl salicylate acted below the untreated control. Fruit damage was more in the methylated spirit field(s) followed by naphthalene (28.33) and the lowest damage recorded in cinnamon oil treatments (18.67). Fruit length and diameter were uniform across the treatments i.e. 17.36 $18.73 \mathrm{~cm}$ and $13.77-14.85 \mathrm{~cm}$ respectively, with coefficient of variation 5.93 and $6.74 \%$.

The mean pest beetle population was highest in the untreated control (31.67) and least in methylated spirit treated plots (22.00) with $13.78 \%$ coefficient of variation. All effects were 
not significantly different across the vegetative and yield parameters evaluated, except for the vine length using Turkey HSD pairwise comparison test at 5\% level.

Table 3 shows the mean protectant effects of the bio-pesticidal materials from Azadirachta (neem) seeds, Delonix seeds, Parkia seeds and Vernonia leave active principles extracted with water as solvent in comparison to an untreated cucumber plants marketer and a positive check of cypermethrin at $2 \mathrm{ml} / \mathrm{l}$ recommended dose.

Vine lengths were more in Delonix treated plants and uniform mean number of branches, which were both not significantly different $(\mathrm{P}>0.05)$. Average leaf area was $27.83-29.63 \mathrm{~cm}^{2}$. While average fruit yield was more in the ANSE treated cucumber plants (186.00) followed by Vernonia leaves treated fruits, lowest mean yield was from the control (103.30). Mean weight of fruits treated with Cypermethrin, were heavier followed by Parkia treated fruits.

Damaged fruits were heaviest in the control, but least in the bio-pesticide treated fruits, however Cypermethrin outperformed in checking against fruit damage. Pest beetle population was more in control (38.33) and lowest (7.67) in the synthetic pesticide treated fruits. However, the bio-pesticides gave varied levels of protection (18.33 -23.67) as against the control (38.33). From the above outcomes, the results were discussed.

\section{DISCUSSION}

Although vegetative parameters gave no significant difference between the cultivars, nevertheless, vine length, number of branches and leaf areas were optimal, translating to average yield. An overview of cucumber production emphasizes growing, harvesting and postharvest practices advertisedly impacts on yield outcome and losses.

Cucumbers are vine crops easily grown on the ground or on poles or trellises to suspend the fruits. Consumer preferences determines cultivar acceptance, there are close to 100 varieties. These plants are highly susceptible to various insect pests particularly the cucumber beetles, Acalymna and Diabrotica. Adults feeding results in wilting and reduced yield. The beetles also damage crops by excessive curving or bumpy fruits; pinched ends, chewing and scarification of fruits; while tender leaves were bronzed or severely skeletonized and witting results due to wounds contamination with the wilt bacterium Erwinia tracheiphilia. All these effects decrease market values of the crop (Synder 2012).

Vine length and other vegetative parameters variability as shown in this study is in agreement with findings of Umeh (2018) expressing great genetic diversity amongst cucumber cultivars. Adinde et al. (2016) reported similar effects of vegetative growth index tied to the genetic adaptability of these cultivars in conjunction with climatic conditions of the agro-ecological zone. Agronomic practices effects being least significant. Yield output is determined by seed rate/plant spacing and genetic components and efficient maximization of climatic and resource utilization (Aritonang et al., 2018). In terms of yield, both cultivars yields were good despite invasion by the beetles, since both cultivars are monoecious. However, the mean number of fruits yield was not significantly different $(\mathrm{P}>0.05)$ as reported by Aritonang et al. (2018).

With increased vine length, the number of branches increases, which invariably affects the fruit length and diameter and translates into weight and total fruit yield. Sharma et al. (2000) 
inferred that yields under field conditions significantly outperformed screen house production, while Poinsett fruit length, weight and yields per plant attributes was at its zenith over marketer.

When vines are well established, plants can tolerate $25-50 \%$ loss of foliage without reduction in yield, except where seedlings are seriously injured by heavy feeding from cucumber beetles. In susceptible cultivars, bacterial wilt may increase risk of total crop failures (100\%). Because cucumber is the most preferred host for these beetles, hence population build up in the fields. Beetle population commuting as indicative of our data, and aesthetics of fruits may wade against catastrophic economic losses, also the threshold population is exceeded in this study, hence the demand for treatment protocol, avoiding synthetic residue problems, which is most dependent upon by small scale producers in the study area.

Cucumber beetles are attracted to host plants by the chemical cucurbitacin which when ingested becomes incorporated into their bodies making them distasteful to predators, hence, protected from predators and parasitoids. So, growers should select cucumber cultivars with lower cucurbitacin levels to decrease their attractiveness to these beetles (Harsimran et al., 2017).

Protection is necessary when beetle population is high and plants are small (Bessin, 2010). A standard foliar application at cotyledon stage will hinder beetle feeding, additional foliar application prevents cucumber bacterial wilt disease, depending on beetle intensity. The coefficient of variation model shows that all treatments gave the same finding and reliability.

Most farmers use synthetic pesticides at an economic threshold of one beetle per plant to prevent damage to the crops. The info-chemical and bio-pesticides provide favorable alternatives to cucumber beetles treatments, to mitigate cosmetic damage to the fruits. The info chemicals naphthalene acted in a push-pull pattern to the beetles on the highly susceptible marketer cultivar. Metcalf, et al. (1980) reported Kairomonal volatiles, e.g. Eugenol, Cinnamyl alcohol and Cinnamaldehyde, mixed with botanicals and other analogs give potent insecticidal and pesticidal effects. In evaluating the effectiveness of these botanicals and info-chemicals, the benefits of these combinations will give most successful management of the beetles while at same time, mitigate against residual poisoning of the fruits and maximize gains.

In the study, neem was reported to have little effects on the beetles' survival or mortality, but anti-feedant traits which significantly reduces plant damage caused by the beetles. Both biopesticides were effective as limiting the beetles' populations. Monitoring plan by surveying 25 plants at random within a field, and an average of $\geq 5$ beetles per plant threshold calls for immediate control measures (Alston and Wood, 2008). They further recommended combined effects of pesticidal materials with other management options for long term management of these beetles. As such foliar applications of these bio-pesticides may be required twice a week, throughout the production period (Bessin, 2010).

\section{CONCLUSION}

This study does not have explanations for the differences in the relative populations of these beetles, fruit yield inconsistencies in number and weight, same for methodological variability across the experiments, perhaps further studies will improve on the search results. Analysis used in this study includes standard tests of significance, such as one way ANOVA, Turkey's multiple comparison tests and variance. Pest abundance gives population dynamics in the 
cucumber beetles activities. Statistically significant impacts were difficult to prove in the study. This low number of plots reduces the power of our data leading to "type two errors". Thus economically important differences may have been shown to be statistically insignificant. Control plots proximity to treatment plots interfered with the treatments because cucumber beetles are highly mobile. Other effects on plant cultivars showed large impacts on yield, which could have blurred treatment effects. Ideally, distance at least $30 \mathrm{~m}$ would buffer the impacts of control plots and alternate treatments on separate plots and subplots. Furthermore, buffer plantings of rows of cucumbers surrounding the experimental plots could be beneficial. Useful management entails deterring beetles and increasing yields, but these effects also impinge yield in certain agro-ecological zones as shown by this study.

\section{REFERENCES}

Abdul-kalam, A; Arif. S., Nkufa, Y., Minanur, R., Sarful I. (2013) Eco-friendly pest control in cucumber (Cucumis sativa L.) field with botanical pesticides. Natural resources 4:404 - 409

Adeyemo, R. and Kuhlmann, F. (2009). Resource use efficiency in urban agriculture in south western Nigeria. Tropicultura, 27(1): 45 - 53.

Adinde, J.O; Anieke, U.K, Uche O.J., Aniakor, A.C; Isani, L.C, Nwagboso, A.A. (2016) Assessment of performance of four cucumber (Cucumis sativus L.) cultivars in Iwotto S.E Nigeria. Int. Journal of Current Research, Bio Sc. Biol. 3(10): 136 - 143

Alston, D.G and Wood, D.R. (2008). Western Striped and Spotted Cucumber beetles A. trivitatum and D. undecipunctata. Utah pests' facts sheets.ENT-118-08.Utah State University Extension and Utah Plant Pest Diagnostic Laboratory.

Aritonang, S.P. Ernitha, P., Fetrus, P.T. (2018). Cucumber plants (Cucumis sativus L.) growth and crop yield of chicken manure fertilized with plant spacing. IOP Conf. series: Earth and Environmental Science. Vol.130:012045.

Ayoola, O.T., and Adeniran, O. N., (2006). Influence of poultry manure and NPK fertilizer on yield and yield components of crops under different cropping system in South West Nigeria. African Journal of Biotechnology, 5:1336 - 1392.

Bessin, R. (2010). Cucumber beetles, ENTFACT-311. College of Agriculture Food and Environment, University of Kentucky, Lexington, KY.

Bruce, J.J.A, Wadhams, J., Woodcock, C.M. (2005a). Insect host location: a volatile situation.Trends plant science, 10:269 - 274

Clarke, S.R., and Strom, B.:L. (2011). Use of Semio-chemicals for southern pine beetle infestation management and resource protection. In R.N. Coulson and K.D Klepzig (Eds). Southern Pine 286 bio-systems engineering, 129, Asheville, NC. 381 - 397pp.

Cook, S.M., Khan, Z.R., and Picket, J.A (2007). The use of push-pull strategies in integrated pest management. Annual Rev. Entomology, 52, 375 - 400.

Diver, S and Hinman, T. (2008). Cucumber beetles: Organic and bio rational integrated pest management. https://attra.ncat.org/attra-pub/summaries/summary.php? 133pp.

Eifediyi, E.K, and Remison, S.U. (2010). Growth and yield of Cucumber (Cucumis sativus,L.) as influenced by farm manure and Organic fertilizer. Journal of Plant Breeding and Crop Science. 2(7); 216-220 
Emeasor, K.C and Nwaliri, N.F. (2012). Plant derived insecticidal control of eggplant shoot and fruit borer (EFSB), Leucinodes orbonalis in Umudike Agroecosystem. In Entomol. Urban Agric., And Wealth creation, $43^{\text {rd }}$ Ann. Conf., Entom. Soc. Nigeria. Benin City. www.esn.org.ng. 63pp

Erika, S.R., Jean, C.B., Mark, A and Laura, C.N (2015). Bacterial wilt of cucurbits. Resurrecting a classic pathosystem. http://dx.doi.org/10. Plant diseases 99(5): 564 574.

Hamman, S.I., Malgwi, A. M. and Michael, C.G. (2012). Comparative efficacy of bioinsecticides and synthetic insecticides on insect pests of cowpea (Vigna ungiiculata L. walp) in Yola, Nigeria, $43^{\text {rd }}$ Ann. Ent. \& Soc. Nig. Conf. Benin City., www.esn.org.ng $63 \mathrm{pp}$

Harsimran, K.G., Gaurav, G and Gillet-Kaufman, J. (2017). Spotted cucumber beetles. Diabrotica undecumpunctata howardi Barber. UF/IFAS Extension EENY572.

Heuskin, S., Verheggen, F.J., Haubruge, E., Wathelet, J.P and Lognay, G. (2011). The use of semio-chemicals slow release devices in integrated pest management strategies. Biotechnology, Agronomy, society and environment. 15(3): 459 - 470.

Hoffman, M.P., Ayayapath, R., Kirkwyland, J. J. (2000). Yield response of pumpkin and winter squash to simulated cucumber beetle (Coleoptera: Chrysomelidae) feeding injury. Economic Entomology. 93 (1): 136 - 140

Hoffmann, M.P., Ayyappath, R. and Gardner, J. (2003). Effect of striped cucumber beetle (Coleoptera: Chrysomelidae) foliar feeding on pumpkin yield. Journal of Entomol. Science, 38 (3): 439 - 448. http://entnemdept.ifas.ufl.edu/creatures/.

Isman, M.B (2006). Botanical insecticides, deterrents and repellents in modern agriculture and an increasingly regulated world. Annual Review Entomology. 51: 45 - 66.

Ivase, T. JP. Nyakuma, B. B., Ogenyi, B.U., Balogun, A.D. and Hassan M.N (2017). Current status, challenge and prospects of bio-pesticide utilization in Nigeria. Acta Universitatis Supientiae Agriculture and Environment, 9:95 - 106.

Jeffery, C (2001). Cucurbitaceae. In. P. Henett (ed.), Mansfelds Encyclopedia of Agricultural and Horticultural crops 31: 1550 - 1557. Springer-verlag, Berlin, Herdelberg.

Kumar, A., Kumar, S., and Pal., A.K.(2008). Genetic variability and characters association for fruits yield and yield traits in cucumber. Indian Journal of Horticulture, 65:423-428.

Kumar, S and Singh, A. (2015). Bio-pesticides present status and future prospects. Journal fertile and pesticides, 6. e. 129. doi: 10.4172/2471-2728. 1000e.129

Mc Guire, R. and Agrawal, A. A. (2005). Trade-offs between the shade-avoidance response and plant resistance to herbivores? Tests with mutan Cucumis sativus. Functional Ecology, 19: 1025 - 1031.

Metcalf, R. L., Metcalf, R.A and Rhodes, A. M. (1980). Cucurbitacins as Kairomones of diabroticite beetles. Proc.Nat.Acad. Sci. 77 (7): 3769 - 3772.

Moran, P.J. (2001). The effects of wilt symptom development and peroxidase induction on interaction between vascular wilt bacteria and cucumber beetles. Entomologia Experimentalis et applicata. 98: 149 - 156.

Natural news (2014). Ten Health Benefits of cucumbers. http://www.naturalnews.com/036769 cucumbers health benefits rehydration.html.

Okonmah, L.U (2011). Effects of different types of staking and their cost effectiveness on the growth yield and yield components of cucumber Cucumis sativus L. Internl. Journal of Agric. Science. 1(15): 292 - 295. 
Onovo, J.A (1992). Survey of disease incidence and severity of cucurbitaceous crops in the Southeast, Annual Cropping Scheme Report. Vegetable Research Programme National Horticultural Research Institute, Mbato, 47p.

Pickett, J. A and Glinwood, R. (2007). Chemical ecology. In. Aphids as crop pests. Ed. HF vanEmden, R. Harrington. Wallington. Oxon, UK., CABI,.publ.

Punzi, J.S., Lamont, M., Haynes, D., Epstein, R.L. (2005). USDA Pesticide data program: Pesticide residues on fresh and processed fruit and vegetables, grains, meats, milk and drinking water. Outlook on pest management. 131 - 137.

Quesada, M., Bollman, K., Stephenson, A.G. (1995). Leaf damage decreases pollen production and hinders pollen performance in Cucurbita taxana. Ecology. 76 (2): 437 443.

Reddick, E. W., Aldrich, J.R., Demilo, A., Davis, J.C. (2000). Potentials for modifying the behavior of the multicolored Asian Lady beetle (Coleoptera: coccinellidae) with plantderived natural products. Ann. Entomol. Society of America, 93:1314 - 21.

Sharma, A. K., Geol, K.R., Kumar, R., (2000). Performance of cucumber cultivar under protected cultivation. Homachal, J. Agric. Research 26: 175 - 177.

Synder, W. (2012). Managing cucumber beetles in an organic farming system. Cornell University Cooperative Extension Publ.28pp.

Theis, N., Kesler, K., Adler, L.S. (2009). Leaf herbivory increases floral fragrance in male but not female Cucurbita pepo sub sp. texana (Cucurbitsceae) flowers. American Journal of Botany, 96(5): 897 - 903.

Tijjani, A, Bashir, K.A; Mohammed, I; Muhammad, A; Gambo, A; and Musa, H. (2016). Biopesticides for Pest control: A review. Journal of Biopesticides and Agriculture. 3(1):6-13.

Umeh, O.A (2018). Evaluation of the performance of different varieties of cucumber (Cucumis sativus L.) in Owerri area of south Eastern Nigeria Internation.al Journal of Agriculture and Rural Development. 21(2): 3807 - 3815.

Umeh, O.A and Ujiako, F.O (2018). Limitations of cucumber (Cucumis sativus L.) Production for Nutrition Security in South East Nigeria. Internl. Journal of Agriculture and Rural Development, SAAT-FUTO, 21(1): 3437 - 3443.

Vander Kraan C. and Ebbers. A (1990). Release rates of tetradecen-1-ol acetate from polymeric formulations in relation to temperature and air velocity. Journal of Chemical Ecology. 16 (4): 1041 - 1058.

Webb, S.E. (2010). Insect-Management for Cucurbits (cucumber, squash, cantaloupe and water melon). ENY - 400. Gainesville; Univ. of Florida, Institute of Food and Agriculture Science. 35pp.

Wheeler, D.A. and Isman M.B (2001). Anti-feedant and Toxic activity of Trichlia americana Extracts against the Larvae of spodoptera litura. Entomologia Experimentalis et Applic. 98(1): $9-16$. 


\section{APPENDIX}

Table 1: Mean Effects of Cucumber Varietal responses to Infestation by the cucumber beetles in 2019

\begin{tabular}{|c|c|c|c|c|c|c|c|c|c|}
\hline \multirow[b]{2}{*}{$\begin{array}{l}\text { TREAT } \\
\text { MENT }\end{array}$} & \multicolumn{3}{|c|}{ Vegetative Attributes/Components } & \multirow[b]{2}{*}{$\begin{array}{l}\text { Fruit } \\
\text { Yield per } \\
\text { plot }\end{array}$} & \multirow[b]{2}{*}{$\begin{array}{l}\text { Fruit } \\
\text { Weight } \\
\text { (g) }\end{array}$} & \multicolumn{3}{|c|}{ Yield Attributes/Components } & \multirow[b]{2}{*}{$\begin{array}{l}\text { Insects } \\
\text { Population }\end{array}$} \\
\hline & Vine length $(\mathrm{cm})$ & $\begin{array}{l}\text { No. of } \\
\text { branches }\end{array}$ & $\begin{array}{l}\text { Leaves } \\
\text { Area } \\
\left(\mathrm{cm}^{2}\right)\end{array}$ & & & $\begin{array}{l}\text { Damaged } \\
\text { fruits }\end{array}$ & $\begin{array}{l}\text { Fruit } \\
\text { Length } \\
(\mathrm{cm})\end{array}$ & $\begin{array}{l}\text { Fruit } \\
\text { Diameter } \\
(\mathrm{cm})\end{array}$ & \\
\hline Premier & 39.57 & 3.33 & 105.80 & $49.67^{b}$ & 11.23 & 3.67 & 13.97 & 17.67 & 154.00 \\
\hline Griffaton & 39.80 & 2.33 & 117.93 & $32.67^{b}$ & 8.27 & 4.55 & 14.67 & 14.67 & 151.00 \\
\hline Seminis & 50.70 & 3.00 & 130.57 & $77.00^{\mathrm{b}}$ & 22.11 & 3.00 & 18.33 & 18.93 & 170.00 \\
\hline Marketer & 45.73 & 3.00 & 108.10 & $111.33^{\mathrm{ab}}$ & 30.73 & 4.00 & 14.00 & 13.00 & 200.33 \\
\hline Poinsett & 47.53 & 2.33 & 141.23 & $141.67^{\mathrm{a}}$ & 31.30 & 3.00 & 16.50 & 17.57 & 187.00 \\
\hline Penino & 50.87 & 2.00 & 115.97 & $77.00^{\mathrm{b}}$ & 14.00 & 3.33 & 14.13 & 16.57 & 173.00 \\
\hline SEM & 5.71 & 0.33 & 14.12 & 36.59 & 11.78 & 1.20 & 2.15 & 1.84 & 18.32 \\
\hline $\mathrm{CV}$ & 21.64 & 21.65 & 20.39 & 77.40 & 39.58 & 58.55 & 24.41 & 19.39 & 18.38 \\
\hline
\end{tabular}

Note: Means with same alphabets within a column are not significantly different $(P<0.05)$ according to Turkey HSD pairwise comparisons Test. 
Table 2: Mean Effects of Info-chemicals on activities of Cucumber beetles infesting cucumber variety marketer in 2019

\begin{tabular}{|c|c|c|c|c|c|c|c|c|c|}
\hline \multirow[b]{2}{*}{ TREATMENTS } & \multicolumn{5}{|c|}{ Vegetative Attributes/Components } & \multicolumn{4}{|c|}{ Yield Attributes/Components } \\
\hline & $\begin{array}{l}\text { Vine } \\
\text { length } \\
(\mathrm{cm})\end{array}$ & $\begin{array}{l}\text { No. of } \\
\text { branches }\end{array}$ & $\begin{array}{l}\text { Leaves } \\
\text { Area } \\
\left(\mathrm{cm}^{2}\right)\end{array}$ & $\begin{array}{l}\text { Fruit Yield } \\
\text { per plot }\end{array}$ & $\begin{array}{l}\text { Fruit } \\
\text { Weight (g) }\end{array}$ & $\begin{array}{l}\text { Damaged } \\
\text { fruits }\end{array}$ & $\begin{array}{l}\text { Fruit } \\
\text { Length } \\
(\mathrm{cm})\end{array}$ & $\begin{array}{l}\text { Fruit } \\
\text { Diameter } \\
(\mathrm{cm})\end{array}$ & $\begin{array}{l}\text { Insects } \\
\text { Population }\end{array}$ \\
\hline Control & $32.11^{\mathrm{ab}}$ & 2.92 & 153.13 & 132.00 & 30.17 & 23.00 & 18.71 & 14.43 & 31.67 \\
\hline Cinnamon Oil & $32.79^{a b}$ & 2.42 & 157.21 & 152.00 & 34.83 & 18.67 & 18.67 & 14.58 & 27.67 \\
\hline Naphthalene & $35.80^{\mathrm{a}}$ & 2.83 & 174.99 & 164.67 & 38.07 & 28.33 & 18.73 & 14.85 & 24.67 \\
\hline Methylated spirit & $30.63^{\mathrm{ab}}$ & 3.25 & 157.71 & 149.67 & 34.53 & 30.33 & 17.36 & 13.77 & 22.00 \\
\hline $\begin{array}{l}\text { B. Complex } \\
\text { Vitamins }\end{array}$ & $32.45^{\mathrm{ab}}$ & 3.00 & 160.92 & 130.00 & 28.83 & 23.33 & 18.71 & 14.86 & 26.00 \\
\hline Methyl Salicylate & $29.29^{\mathrm{b}}$ & 2.42 & 149.74 & 138.33 & 29.90 & 24.33 & 18.17 & 14.77 & 28.00 \\
\hline SEM & 1.35 & 0.27 & 6.01 & 15.68 & 3.19 & 4.33 & 0.63 & 0.57 & 2.12 \\
\hline $\mathrm{CV}$ & 7.25 & 16.40 & 6.53 & 18.81 & 16.90 & 30.41 & 5.93 & 6.74 & 13.78 \\
\hline
\end{tabular}

Note: Means with same alphabets within a column are not significantly different $(P<0.05)$ according to Turkey HSD pairwise Comparisons Test. 
Table 3: Mean Protectant Effects of Bio-pesticides on Cucumber, Marketer infested by cucumber beetles in 2019.

\begin{tabular}{|c|c|c|c|c|c|c|c|}
\hline \multirow[t]{2}{*}{ Treatments } & \multicolumn{3}{|c|}{ Vegetative Components } & \multirow[b]{2}{*}{ Fruit Yield } & \multirow[b]{2}{*}{$\begin{array}{l}\text { Fruit weight } \\
(\mathrm{g})\end{array}$} & \multicolumn{2}{|c|}{ Yield Components } \\
\hline & $\begin{array}{l}\text { Vine Length } \\
(\mathrm{cm})\end{array}$ & $\begin{array}{l}\text { No. of } \\
\text { Branches }\end{array}$ & $\begin{array}{l}\text { Leaf Area } \\
\left(\mathrm{cm}^{2}\right)\end{array}$ & & & Fruit Damage & $\begin{array}{l}\text { Insect } \\
\text { Population }\end{array}$ \\
\hline Control & 29.60 & 2.67 & 28.73 & 103.30 & 05.00 & 59.80 & $38.33^{\mathrm{a}}$ \\
\hline ANSE & 28.97 & 2.67 & 28.60 & 186.00 & 11.00 & 29.90 & $23.67^{\mathrm{a}}$ \\
\hline ADSE & 40.27 & 2.67 & 28.77 & 130.00 & 10.00 & 32.60 & $20.33^{\mathrm{b}}$ \\
\hline APSE & 39.07 & 2.67 & 27.83 & 123.30 & 21.00 & 30.60 & $18.67^{\mathrm{b}}$ \\
\hline AVLE & 37.00 & 2.33 & 28.37 & 140.00 & 13.00 & 54.57 & $18.33^{\mathrm{b}}$ \\
\hline Cypercal $^{\circledR}$ & 39.63 & 2.67 & 29.63 & 133.30 & 22.00 & 26.10 & $7.67^{\mathrm{a}}$ \\
\hline SEM & 7.30 & 0.33 & 0.73 & 16.30 & 6.70 & 9.95 & 2.01 \\
\hline $\mathrm{CV}$ & 35.39 & 22.11 & 4.42 & 20.95 & 8.74 & 44.33 & 16.48 \\
\hline
\end{tabular}

Note: Means with the same alphabet within a column are not significantly different $(P<0.05)$ according to Turkey HSD pairwise comparisons test. 